\title{
KONFLIK DALAM NOVEL CINTA DALAM DIAM KARYA SHINEEMINKA
}

\author{
${ }^{1}$ Etiwati, ${ }^{2}$ La Ode Syukur, ${ }^{3}$ Marwati \\ pbsi.fkip.uho@gmail.com \\ 1,2,3, Jurusan Pendidikan Bahasa dan Sastra Indonesia, \\ Fakultas Keguruan dan Ilmu Pendidikan, Universitas Halu Oleo \\ Kampus Hijau Bumi Tridharma Anduonohu, Kendari, Indonesia
}

\begin{abstract}
ABSTRAK
Tujuan dalam penelitian ini adalah untuk mendeskripsikan wujud konflik yang terdapat dalam novel Cinta Dalam Diam karya Shineeminka. Jenis penelitian ini adalah penelitian kepustakaan (library research). Dikatakan kajian kepustakaan, karena kajian dalam penelitian ini berupa data tertulis dan kegiatan dalam mencari, mengumpulkan, dan mendapatkan data-data yang diperlukan dengan cara menelaah dan menganalisis konflik apa saja yang terdapat pada novel Cinta Dalam Diam karya Shineeminka. Metode penelitian yang digunakan dalam penelitian ini adalah metode deskriptif kualitatif. Metode deskriptif bertujuan untuk menggambarkan objek secara rinci mengenai konflik dalam novel Cinta Dalam Diam karya Shineeminka. Dikatakan kualitatif karena dalam menjelaskan konsep-konsep atau kalimat bukan menggunakan angka-angka. Berdasarkan hasil penelitian ini menemukan wujud konflik yang terdapat dalam novel Cinta Dalam Diam karya Shineeminka yaitu konflik internal dan konflik ekternal. Konflik internal salah satunya yaitu pertentangan antara keinginan Zahra dan Mama Zahra sehingga ia terpaksa menuruti apa yang diinginkan oleh mamanya walau sebenarnya Zahra tidak setuju. Sedangkan konflik eksternal yang terdiri dari 3 bagian. Pertama, konflik fisik yaitu adanya perseteruan yang menyebabkan Ali meninju Andra ketika Andra mengakui bahwa ia istri Ali, yakni Zahra. Kedua, konflik sosial yang terjadi karena percocekan antara Mama Ayana dengan Kelurga Zahra sehingga menimbulkan perdebatan masalah mengenai musibah yang menimpah Mama Ayana. Ketiga, konflik alam yaitu konflik yang disebabkan adanya pembenturan antara tokoh dengan alam mislnya pada tokoh Zahra yang tidak sengaja kesandung di batu ketika di jalan.
\end{abstract}

Kata Kunci: novel, konflik, objektif 


\section{PENDAHULUAN}

Karya sastra adalah seni kreatif yang objeknya manusia dan kehidupan dengan menggunakan bahasa sebagai mediumnya. Wicaksono (2014: 1) mengatakan bahwa karya sastra adalah suatu bentuk dan hasil pekerjaan seni kreatif yang objeknya adalah manusia dan kehidupannya dengan menggunakan bahasa sebagai mediumnya. Bahasa digunakan secara istimewa dalam karya sastra, terutama dalam menjalankan fungsi komunikasi untuk menyampaikan informasi secara maksimal. Karya sastra yang ditulis merupakan ungkapan masalahmasalah manusia dan kemanusiaan, tentang makna hidup dan kehidupa, melukiskan penderitaan-penderitaan manusia, perjuangannya, kasih sayang dan kebencian, nafsu, dan segala yang dialami manusia, Esten (Wicaksono, 2014: 3). Bentuk pengungkapan inilah yang merupakan hasil kepiawaian pengarang dalam menggambarkan segala aspek kehidupan manusia lewat ekspresi pengarang. Karya sastra memberi kenikmatan dan kesenangan. Karya sastra yang baik, isinya bermanfaat dan cara pengungkapan bahasanya pun indah. Karya sastra yang diciptakan pengarang mempunyai maksud tertentu. Karya sastra tidak hanya menghibur, tetapi merupakan alat menyampaikan wejangan-wejangan atau nasihat, pendidikan dan sebagainya. Dengan karyanya, seorang pengarang bermaksud menyampaikan gagasangagasannya, pandangan hidup atas kehidupan sekitar dengan cara menarik dan menyenangkan pembaca.

Salah satu karya sastra yang mengungkap seluk-beluk kehidupan manusia adalah novel. Novel merupakan gambaran hidup tokoh yang menceritakan perjalanan hidup dan juga pengalaman hidup pada setiap tokoh cerita. Perjalanan hidup pada tokoh dalam novel digambarkan dengan lengkap dan jelas. Setiap tokoh cerita diberi gambaran fisik, konflik dan kejiwaan yang berbeda-beda dengan tokoh cerita yang lain, sehingga isi dari cerita tersebut nampak nyata dan menjadi hidup. Salah satu pengarang yang menulis novel adalah Shineeminka.

Shineeminka merupakan penulis wattpad yang sudah menulis banyak cerita. Karya Shineeminka antara lain, yaitu Air Mata Cinta, Bukan Pernikahan Impian, Aluna, I'm With You, Hujan, Sakha dan Shabiya, Damian dan Evelyn, Tentang Rindu, Laura, Aliandra, Mahabbah, dan Cinta Dalam Diam. Shineeminka lahir di Bogor, 23 Februari 1994. Pendidikan terakhir di SMK Negeri 1 Bogor.

Dalam novel tersebut, permasalahan kehidupan diceritakan dalam bentuk konflik. Karena novel bercerita tentang kehidupan sosial masyarakat yang tidak bisa terpisah dengan konflik, maka wajarlah konflik dihadirkan pada novel sebagai komponen penting dalam novel. Konflik menjembatani setiap peristiwa menuju klimaks. Konflik dianggap sangat penting dalam novel, karena konflik merupakan salah satu elemen penting yang membangun unsur alur dalam novel. Menurut Stanton (2007: 31), dua elemen yang membangun alur adalah "konflik" dan "klimaks". Konflik juga menjadi bagian yang penting guna membuat pembaca terfokus pada novel.

Salah satu karya sastra yang menghidangkan berbagai konflik yang menarik di dalamnya adalah novel Cinta Dalam Diam. Bermula dari Ibu Zahra yang menyuruhnya menggunakan gamis, dan kerudung yang syar'i, saat ingin mendatangi pengajian. Zahra yang tidak ingin durhaka kepada ibunya mengikuti apa yang dikatakan ibunnya, walaupun dengan rasa kesal di dalam hati Zahra sama sekali tidak ingin menggunakan pakaian itu dikarenakan dia merasa belum pantas menggunakannya. Hari demi hari Zahra mulai belajar hijrah karena dukungan dari mamanya dan membaca buku kisah Ali dan Fatimah Azzahra. Ia dipertemukan dengan Ali disebuah pengajian rutin di rumah Tante Anisa, yaitu Ibu dari Ali. Yang merupakan sahabat dekat Ibu Zahra. Mereka kemudian dijodohkan meskipun Zahra merasa belum 
siap. Namun sebagai bakti kepada orang tuanya ia pun menerima perjodohan itu. Ali merupakan seorang dokter sekaligus juga dosen di kampus Zahra. Ali lulusan dari Malaysia.

Dari uraian tersebut, yang menjadi objek dalam penelitian ini yaitu konflik dalam novel Cinta Dalam Diam karya Shineeminka. Alasan dipilihnya novel karya Shineeminka yaitu karena pengarang termasuk seorang penulis muda yang berkarir dimedia sosial dan media cetak. Penulis juga melihat sudut pandang dari pengarang yang aktif dimedia sosial sehingga terlihat berbeda dengan penulis novel lainnya yang tidak menggunakan media sosial. Dengan perbedaan yang dilakukan oleh pengarang, penulis merasa penasaran dengan tulisan yang di tulis oleh Shineeminka. Selanjutnya adanya pertimbangan pemilihan novel yang penulis teliti yakni dari sudut jumlah pembaca. Sejak awal terbit pada bulan Mei 2017 Novel Cinta Dalam Diam karya Shineeminka ini sangat diminati oleh pembaca pecinta novel, terbukti pada saat percetakan pertama, pembaca novel Cinta Dalam Diam karya Shineeminka sudah dibaca sebanyak tiga juta kali yang tertera di cover novel. Sampai saat ini, grafik pembaca novel Cinta Dalam Diam karya Shineeminka terus meningkat, sampai sekarang mencapai 5,5 juta kali pembaca di media sosial wattpad. Dengan perbedaan jumlah pembaca yang signifikan membuat peneliti tertarik untuk memilih novel tersebut. Masalah dalam penelitian ini adalah bagaimanakah wujud konflik yang terdapat dalam novel Cinta Dalam Diam Karya Shineeminka?

Penelitian ini bertujuan untuk mendeskripsikan wujud konflik yang terdapat dalam novel Cinta Dalam Diam Karya Shineeminka. Adapun manfaat yang diharapkan dalam penelitian ini, yaitu:

1. Penelitian ini diharapkan mampu menambah pengetahuan tentang studi analisis terhadap sastra Indonesia, terutama dalam bidang penelitian novel
Indonesia yang memanfaatkan teori sastra.

2. Sebagai bahan bacaan yang memudahkan para pembaca dalam memahami konflik dalam novel pada umumnya, khususnya novel Cinta Dalam Diam karya Shineeminka.

3. Hasil penelitian ini bisa menjadi referensi dalam penelitian karya sastra dan menjelaskan pentingnya konflik dalam membangun sebuah cerita dalam karya sastra.

4. Penelitian ini diharapkan mampu memberi pengetahuan pada pembaca mengenai konflik dalam novel Cinta Dalam Diam karya Shineeminka.

Menurut Sehandi (2016: 123) konflik adalah salah satu hal yang merupakan bagian yang tak terpisahkan dari kehidupan manusia bahkan terkadang menjadi penentu alur hidup seseorang adalah konflik. Konflik sendiri sangat luas cakupannya. Dalam ilmu sosial, teori konflik sangat populer sebab konflik merupakan masalah sosial yang sangat umum terjadi, kapan dan dimana saja.

Konflik (conflict), yang notabene adalah kejadian yang tergolong penting (jadi, ia akan berupa peristiwa nasional, utama, atau kernel), merupakan unsur yang esensial dalam pengembangan plot sebuah fiksi. Kemampuan pengarang untuk memilih dan membangun konflik melalui berbagai peristiwa (baik aksi maupun kejadian) akan sangat menentukan kadar kemenarikan, kadar suspense, cerita yang dihasilkan. Misalnya peristiwa-peristiwa manusiawi yang seru, yang sesansional, yang saling berkaitan dengan yang lain dan menyebabkan munculnya konflik-konflik yang kompleks, biasanya cenderung disenangi pembaca. Bahkan sebenarya yang dihadapi dan menyita perhatian pembaca sewaktu membaca suatu karya naratif adalah peristiwa-peristiwa konflik (Nurgiyantoro, 2013: 178).

Menurut Meredith dan Fitzgerald (Nurgiyantoro, 2013: 179) konflik menunjuk pada sesuatu yang bersifat tidak menyenangkan yang terjadi dan atau 
dialami oleh tokoh-tokoh cerita yang jika tokoh-tokoh itu mempunyai kebebasan untuk memilih, ia (mereka) tidak akan memilih peristiwa itu menimpa dirinya. Konflik adalah sesuatu yang "dramatik", mengacu pada pertarungan antara dua kekduatan yang seimbang, menyiratkan adanya aksi dan aksi balasan (Wellek, 1995: 285).

Berdasarkan beberapa pendapat sebelumnya, maka dapat disimpulkan bahwa konflik adalah pertentangan yang dialami tokoh dalam novel, yakni pertentangan tokoh dialami tokoh di dalam dirinya maupun di luar dirinya yang disebabkan adanya perbedaan keinginan, benturan ego, serta pertentangan lainnya yang menyebabkan ketegangan dalam cerita.

Menurut Wicaksono (2014: 178) konflik internal atau konflik batin adalah konflik yang terjadi dalam hati atau jiwa seseorang tokoh. Konflik internal (atau: konflik kejiwaan) adalah konflik yang terjadi di dalam hati, jiwa seseorang tokoh (atau tokoh dalam cerita).

Dalam karya sastra, konflik internal terdiri dari berbagai macam wujud. Konflik utama dalam sebuah cerita mungkin berupa pertentangan antara kesetiaan dan penghiyanatan, cinta kekasih dan cinta tanah air (atau cinta yang lain), kejujuran dan keculasan, perjuangan tanpa pamrih dan penuh pamrih, kebaikan dan kejahatan, keberanian dan kekuatan, kesucian moral dan kejahatan moral, perasaan religiositas dan bukan reriligositas, peperangan dan cinta perdamaian, dan sebagainya (Nurgiyantoro, 2013: 138).

Konflik eksternal adalah konflik yang terjadi antara seorang tokoh dengan sesuatu yang ada di luar dirinya, mungkin dengan lingkungan alam atau mungkin dengan lingkungan manusia atau tokoh lain. Dengan demikian, konflik ekternal dapat dibedakan ke dalam tiga kategori, yaitu konflik fisik, konflik sosial, dan konflik elemental (Nurgiyantoro, 2013: 181).
Konflik fisik diartikan adanya ketegangan antara tokoh-tokoh cerita yang berkaitan dengan perseteruan yang melibatkan anggota tubuh mnausia, seperti: meninju, menendang, demonstrasi, peperangan, baku hantam berkelahi, dan sebagainya.

Konflik sosial menurut Nurgiyantoro (2009: 124) adalah konflik yang disebabkan oleh adanya kontak sosial antar manusia,atau masalah yang muncul akibat adanya hubungan antarmanusia. Ia antara lain berwujud masalh perburuhan, penindasan, percekcokan, peperangan, atau kasus-kasus hubungan sosial lainnya.

Konflik elemental adalah konflik yang disebabkan adanya perbenturan antara tokoh dan lingkungan alam. Misalnya adanya banjir besar, kemarau panjang, gunung meletus, dan sebagainya yang memicu munculnya masalah.

Pendekatan objektif adalah pendekatan kajian sastra yang menitik beratkan kajiannya pada karya sastra, Junus (Siswanto, 2013: 169). Pendekatan objektif merupakan pendekatan yang terpenting sebab pendekatan apa pun yang dilakukan pada dasarnya bertumpu atas karya sastra itu sendiri. Secara historis pendekatan ini dapat ditelusuri pada zaman Aristoteles dengan pertimbangan bahwa sebuah tragedi terdiri atas unsur-unsur kesatuan, keseluruhan, kebulatan, dan keterjalinan. Oragnisasi keempat unsur itulah yang kemudian membangun struktur cerita yang disebut plot, Ratna (2009: 73).

Pendekatan objektif memusatkan perhatian semata-mata pada unsur-unsur di dalam karya sastra itu sendiri yang disebut unsur intrinsik. Konsekuensi logisnya adalah pendekatan ini mengabaikan bahkan menolak segala unsur di luar karya sastra yang disebut unsur ekstrinsik, seperti historis, sosiologis, psikologis, politis, dan unsur sosiokultural lainnya, termasuk biografis. Pemahaman dipusatkan pada analisis terhadap unsur-unsur di dalam karya sastra dengan mempertimbangkan keterjalinan antarunsur di satu pihak dan 
unsur-unsur dengan totalitas karya sastra di pihak yang lain, Ratna (2009: 73).

Nurgiyantoro (Marsanti, 2012: 170171) pendekatan strukturalisme dapat dipandang sebagai salah satu pendekatan (penelitian) kesusastraan yang menekankan kajian hubungan antara unsur-unsur pembangun karya sastra yang bersangkutan. Analisis struktural dapat dilakukan dengan mengidentifikasi, mengkaji, mendefinisikan fungsi dan hubungan antarstruktur intrinsik. Identifikasi dan deskripsi misalnya tema dan amanat, plot, tokoh, penokohan, latar, dan lain-lain.

Pada dasarnya analisis struktural bertujuan memaparkan secermat mungkin fungsi dan berkaitan berbagai unsur karya sastra yang secara bersama menghasilkan sebuah kemenyeluruhan. Tidaklah cukup dilakukan hanya sekedar mendata unsur tertentu sebuah karya fiksi, akan tetapi yang lebih penting ialah menunjukan bagaiamana hubungan antarunsur dan sumbangan apa yang diberikan terhadap tujuan estetik dan makna keseluruhan yang ingin dicapai. Hal tersebut perlu dilakukan mengingat karya sastra adalah sebuah struktur yang kompleks, dan hal inilah yang membedakan karya yang satu dengan karya yang lain, Nurgiyantoro (2013: 60).

Dalam Kamus Besar Bahasa Indonesia (Achmad, 2015: 165) novel merupakan karangan prosa yang panjang, yang mengandung rangkaian cerita kehidupan seseorang dengan orang disekelilingnya dengan menonjolkan watak sifat setiap pelaku.

Novel berasal dari kata Itali yang berarti novella (yang dalam bahasa Jerman novelle). Secara harfiah novella berarti sebuah barang baru yang kecil, dan kemudian diartikan sebagai cerita pendek dalam bentuk prosa. Dewasa ini istilah novella dan novelle mengandung perngertian yang sama dengan istilah Indonesia novelet (Inggris: novelette) yang berarti sebuah karya prosa fiksi yang panjangnya cukupan tidak terlalu panjang, namun juga tidak terlalu pendek, Nurgiyantoro (2013: 11-12).

Wicaksono

(2014:

menambahkan, selain menampilkan unsur keindahan hiburan dan keseriusan, karya sastra (novel) juga cenderung membuktikan memiliki unsur pengetahuan. Hal ini berdasar pada pendapat Effendi (dalam Wicaksono, 2014: 116) menyebut sastra sebagai kenikmatan dan kehikmahan, yaitu kenikmatan dalam arti sastra memberi hiburan yang menyenangkan dan kenikmatan dalam arti sastra memberi sesuatu atau nilai yang berguna bagi kehidupan.

Dari beberapa pendapat sebelumnya dapat disimpulkan bahwa novel adalah bentuk karya sastra berbentuk prosa dan di dalamnya terdapat unsur-unsur pembangun novel yang mengandung serangkaian cerita kehidupan yang berusaha menggambarkan atau melukiskan kehidupan seseorang atau tokoh.

Menurut Waluyo (Wicaksono, 2014: 122) memberikan ciri-ciri novel sebagai berikut: adanya perubahan nasib dalam tokoh cerita, novel memiliki beberapa episode dalam kehidupan tokoh utamanya, novel tidak menceritakan tokoh utamanya sampai mati, dan dalam novel tidak dituntut kesatuan gagasan, impresi, emosi, dan setting seperti dalam cerita pendek.

Novel memiliki ciri-ciri sebagai berikut.

1) menceritakan sebagian kehidupan yang luar biasa.

2) terjadinya konflik hingga menimbulkan perubahan nasib.

3) terdapat beberapa alur atau jalan cerita.

4) terdapat beberapa insiden yang mempengaruhi jalan cerita.

5) perwatakan atau penokohan dilukiskan secara mendalam.

Sebuah novel merupakan sebuah totalitas yang mempunyai bagian-bagian, unsur-unsur yang saling berkaitan satu dengan yang lain secara erat dan saling menggantugkan. Novel memiliki unsurunsur pembangunnya baik dari dalam maupun di luar karya sastra, unsur-unsur 
tersebut yaitu unsur intrinsik dan ekstrinsik. Dari penjelasan tersebut maka, peneliti ini difokuskan menelaah unsur intrinsik khususnya konflik.

Unsur intrinsik adalah unsur-unsur yang membangun karya sastra itu sendiri. Unsur-unsur inilah yang menyebabkan suatu teks hadir sebagai teks sastra, unsurunsur yang secara faktual akan dijumpai jika orang membaca karya sastra. Unsur intrinsik sebuah novel adalah unsur-unsur yang secara langsung turut serta membangun cerita. Kepaduan berbagai unsur intrinsik inilah yang membuat novel terwujud. Atau sebaliknya, jika dilihat dari sudut kita pembaca, unsur-unsur (cerita) inilah yang akan dijumpai jika kita membaca sebuah novel. Unsur-unsur intrinsik terdiri dari tema, latar, plot, penokohan, sudut pandang penceritaan, bahasa atau gaya bahasa, dan amanat (Nurgiyantoro, 2013: 30).

Tema adalah sebuah makna yang terkandung dalam sebuah karya sastra yang merupakan ide dasar sebuah cerita yang di bangun oleh pengarang dengan memanfaatkan unsur-unsur instrinsik untuk membangun sebuah cerita.

Nurgiyantoro (2013: 302) mengatakan bahwa latar disebut juga sebagai landas tumpu, menunjuk pada pengertian tempat, hubungan waktu sejarah, dan lingkungan sosial tempat terjadinya peristiwaperistiwa yang diceritakan.

Tokoh dapat didefinisikan sebagai "pelaku cerita" atau "karakterisasi". Ini adalah seluruh kesatuan antara tokoh dan karakterisasinya karena tidak jarang menyebutkan nama karkter tertentu secara langsung kita untuk memahami karakterisasinya, Wicaksono (2014: 211). Penokohan dalam karya fiksi dibedakan menjadi tiga yaitu tokoh protagonis, tokoh antagonis dan tokoh tritagonis. Penokohan dan karakteristik sering juga diartikan sebagai karakter dan perwatakan, menunjuk pada penempatan tokoh-tokoh tertentu dengan watak-watak tertentu dalam sebuah cerita.
Sudut pandang atau pusat pengisahan (point of view) dipergunakan untuk menentukan arah pandang pengarang terhadap peristiwa-peristiwa di dalam cerita sehingga tercipta suatu kesatuan cerita yang utuh. Oleh karena itu, sudut pandang pada dasarnya adalah visi pengarang, dalam arti bahwa ia merupakan sudut pandangan yang diambil oleh pengarang untuk meliihat peristiwa dan kejadian dalam cerita, Sayuti (2017: 177).

Menurut Nurgiyantoro (Karnastuti dan Nazaruddin, 2017: 2-3) amanat merupakan petunjuk yang sengaja diberikan oleh pengarang tentang berbagai hal yang berhubungan dengaan masalah kehidupan, seperti sikap, tingkah laku, dan sopan santun pergaulan. Melalui cerita, sikap, dan tingkah laku tokoh-tokoh itulah pembaca diharapkan dapat mengambil hikmah dan pesan-pesan moral yang disampaikan atau diamanatkan.

Plot atau alur merupakan rangkaian atau tahapan kejadian atau peristiwa yang dialami tokoh-tokoh dalam cerita. Plot menjadi bagian yang sangat penting dalam sebuah cerita karena plot berisi kejadiankejadian dalam cerita yang disukai pembaca.

Metode penelitian yang digunakan dalam penelitian ini adalah metode deskriptif kualitatif. Metode deskriptif bertujuan untuk menggambarkan objek secara rinci mengenai konflik dalam novel Cinta Dalam Diam karya Shineeminka. Dikatakan kualitatif karena dalam menjelaskan konsep-konsep atau kalimat bukan menggunakan angka-angka.

Jenis penelitian ini adalah penelitian kepustakaan (library research). Dikatakan kajian kepustakaan, karena kajian dalam penelitian ini berupa data tertulis dan kegiatan dalam mencari, mengumpulkan, dan mendapatkan data-data yang diperlukan dengan cara menelaah dan menganalisis konflik apa saja yang terdapat pada novel Cinta Dalam Diam karya Shineeminka.

Data yang digunakan dalam penelitian ini adalah data tertulis berupa konflik yang 
terdapat dalam novel Cinta Dalam Diam karya Shineeminka. Sumber data dalam penelitian ini adalah novel Cinta Dalam Diam karya Shineeminka yang diterbitkan oleh Bintang Media, Jakarta, tahun 2017 cetakkan pertama dengan tebal 368 halaman.

Teknik yang digunakan untuk mengumpulkan data dalam penelitian ini adalah teknik analisis isi (analisis konten) digunakan untuk menganalisis isi komunikasi serta isi laten dalam novel Cinta Dalam Diam karya Shineeminka. Teknik analisis data yang digunakan dalam penelitian ini adalah analisis objektif, yaitu pendekatan dalam ilmu sastra yang kerjanya menganalisis karya sastra yang membangun karya sastra dari dalam. Hal ini sesuai dengan masalah utama dalam penelitian ini, yaitu konflik dalam novel Cinta Dalam Diam karya Shineeminka. Langkah-langkah yang dilakukan dalam menganalisis data dalam penelitian ini yaitu:

1. Mengidentifikasi konflik yang terdapat dalam novel Cinta Dalam Diam karya Shineeminka.

2. Kemudian mengklarifikasi konflik tokoh, selanjutnya tokoh-tokoh itu dedeskripsikan dengan kutipan yang menunjukkan tokoh-tokoh tersebut mengalami konflik dengan paparan kebahasaan.

3. Kemudian dideskripsikan masingmasing konflik sebagai hasil akhir dengan penelitian menggunakan pendekatan objektif.

4. Interpretasi data, memberikan gambaran secara umum tentang hasil penelitian yang diperoleh, hal tersebut tampak pada simpulan hasil penelitian.

\section{HASIL PENELITIAN}

Novel Cinta Dalam Diam karya Shineeminka ini terdapat tokoh-tokoh yang berperan di dalamnya. Namun, dalam penelitian ini penulis fokus pada tokoh utama dan beberapa tokoh lainnya. Hal ini dilakukan sebab tidak semua tokoh mengalami konflik. Dalam novel ini, ada
32 tokoh yang dituliskan pengarang, sebagai berikut ini, yaitu Zahra, Ibu Zahra, Ayah Zahra, Ali, Nisya, Ibu Ali, Mang Ujang, Citra, Nina, Fadlan, Rendi, Pak Ginajar, Rizal, Zaky, Andra, Nana, Ayana, Mama Ayana, Ayah Ayana, Dylan, Dio, Zidanc, Haris, Danang, Niko, Bagas, Dani, Mariana, Neni, Budhe, Shaka, dan Dokter. Setelah dilakukan analisis data, hanya 8 tokoh yang terlibat konflik dalam novel Cinta Dalam Diam karya Shineeminka baik konflik internal maupun konflik eksternal. Tokoh-tokoh tersebut yaitu Zahra, Ibu Zahra, Ali, Ibu Ali, Ayana, Andra, Mama Ayana dan Danang. Dimana 24 tokoh lainnya tidak mengalami konflik karena mereka hanya penyebab muculnya konflik serta bersifat sebagai tokoh tambahan.

Alur merupakan rangkaian cerita yang dibentuk oleh tahapan-tahapan peristiwa sehingga menjalin sebuah cerita yang dihadirkan oleh para pelaku dalam cerita. Analisis alur dilakukan untuk mengetahui satuan urutan cerita (sekuen) sekaligus mengklasifikasi dan mengidentifikasinya. Sehingga akan diperoleh data tentang jalinan peristiwa yang diceritakan. Berikut ini urutan peristiwa dalam novel Cinta Dalam Diam karya Shineeminka yang diurut berdasarankan urutan sekuennya dapat dilihat di bawah ini:

1. Zahra terpaksa menuruti permintaan mamanya memakai pakaian syar'i.

2. Zahra dan Ibunya sampai di rumah Tante Anisa.

3. Tante Anisa memperkenalnkan Zahra dengan anaknya yang bernama Ali.

4. Zahra merasa kesal dengan Ali yang bersikap tidak sopan padanya.

5. Ibu Zahra menasehati Zahra yang tidak ikut pengajian.

6. Zahra keasyikan baca buku hingga lupa waktu.

7. Zahra berangkat ke Kampus.

8. Zahra bertemu Citra di gerbang kampus.

9. Citra menuduh Zahra yang berpakaian ala-ala ustazah semata-mata ingin 
mencari perhatikan kepada Pak Ali, Dosen di fakultasnya.

10. Citra curhat ke Zahra bahwa Pak Ali ganteng sekali dan orangnya sholeh.

11. Jam pertama telah selesai, Zahra ke Masjid.

12. Zahra ke Kantin yang berada dekat dengan fakultas.

13. Zahra merasa kesal dengan bullyan Fadlan dan Rendi.

14. Di perjalanan pulang Zahra membawa Pak Ali ke Rumah Sakit Amanda disebabkan karena kecelakaan ditabrak geng motor SMA yaitu Zaky, Rizal dan Andra.

15. Zahra telpon Ibu Al, beruntung Ali selamat.

16. Zahra dan Ali di jodohkan oleh kedua orang tua mereka.

17. Ali datang melamar Zahra, yang menurut Zahra terlalu cepat.

18. Resepsi Zahra dan Ali dilakukan di Ballroom hotel.

19. Ali melihat Ayana di hari pernikahannya dengan Zahra.

20. Ali sudah jatuh cinta pada Ayana saat pertama kali bertemu di Kairo pada saat ia sedang menuntut ilmu di luar negeri.

21. Ali selalu berdoa agar suatu hari Ayana bisa menjadi istrinya.

22. Ayana memiliki nama panggilan kepada teman-temannya dengan sebutan Zahra karena ia selalu meladani sikap-sikap seperti Fatimah Azzhara.

23. Setelah menikah, Ali sadar bahwa wanita yang dihikahinya bukan Ayana melainka Zahra.

24. Zahra hanya bisa diam dan benci setelah mengetahui bahwa Ali sebenarnya mencintai Ayana.

25. Lima bulan berlalu tumbulah benihbenih cinta diantara Ali dan Zahra.

26. Ayana melamar kerja di rumah sakit tempat Ali bekerja.

27. Ayana mengirim surat untuk Ali.

28. Ali sangat senang ketika Ayana masih cinta padanya.
29. Perlahan sikap Ali kepada Zahra seketika berubah, jarang di rumah.

30. Zahra akhirnya menyelidiki Ali yang mulai berubah.

31. Zahra sakit hati kepada Ali melihatnya makan di restoran bersama Ayana.

32. Zahra kira Ali telah melupakan Ayana, ternyata ia salah besar.

33. Ali bingung disisi lain ia sudah menyayangi Zahra sebagai istrinya, dan disisi lain juga sangat senang karena cintanya tidak bertepuk sebelah tangan dan igin mennikahi Ayana.

34. Ali meminta kepada Ibunya untuk merestui hubungannya dengan Ayana dan membantunya mengatakany kepada Zahra.

35. Ibu Ali mengatakan keinginan Ali pada Zahra.

36. Zahra merasa kecewa kepada Ibu mertuanya karena telah mengikhlaskan Ali menikah lagi.

37. Ali berkata jujur kepada Zahra bahwa ia tidak mencintainya.

38. Zahra mengurung diri di dalam kamar mandi dalam keadaan hatinya hancur mendengar ucapan Ali.

39. Zahra mengalami keguguran bahkan dia dan Ali tidak mengetahui hal tersebut.

40. Ali drop mendengar bahwa Zahra mengalami keguguran.

41. Ali merasa bahwa dia adalah laki-laki yang jahat.

42. Danang sahabatnya dan Fadlan sangat kecewa terhadap sikap Ali kepada Istrinya.

43. Keluarga Zahra dan mertuanya datang menjenguk Zahra di rumah sakit.

44. Ibu Zahra sangat kecewa atas perbuatan Ali terhadap anak semata wayangnya itu.

45. Zahra dan Keluarganya pergi ke Malang untuk menenangkan perasaan Zahra.

46. Ali menyusul Zahra di Malang untuk meminta maaf atas perbuatannya. 
47. Zahra menunggu Ali yang sudah tiga hari tidak pernah datang ke rumah Neneknya.

48. Ali dilarikan ke rumah sakit karena terkena demam berdarah.

49. Zahra beserta keluaarga berdatangan ke rumah sakit untuk menjenguk Ali.

50. Zahra minta maaf kepada Ali karena berlaku jahat menjadi istri.

51. Ali sadar seketika sadar tidak sengaja mendengar ucapan kata minta maaf istrinya, ia langsung memaafkannya.

52. Ayana dan Danang datang menjenguk Ali di rumah sakit.

53. Danang memberitahu Ali bahwa Ayana hamil dan sekarang ia ngaku bahwa Ayah buah hati yang sedang ia kadung yaitu dari anak Ali.

54. Dylan diam-diam mengikuti Ayana sampai ke rumah sakit untuk menemui Ali.

55. Dylan mengatakan di depan Ali bahwa buah hati yang dikandung Ayana bukanlah anakmu akan tetapi ini anak dariku karena semua ini adalah kesalahanku.

56. Dylan minta maaf karena telah menyakiti Ayana.

57. Ayana menyesal atas semua perbuatan jahatnya kepada Zahra dan Ali.

58. Hari jumat segala peralatan yang Ali pakai di rumah sakit selama dua minggu akan dilepaskan.

59. Allah telah menunjukkan kekuasaanNya kini Ali bagun dari komanya.

60. Hari demi hari kondisi Ali membaik.

61. Ali minta maaf pada Zahra karena telah merepotkannya selama ia terbaring di rumah sakit.

62. Ali sangat beruntung memiliki istri seperti Zahra.

63. Ali peluk Zahra karena ia sangat mencintainya.

64. Ali dan Zahra bersantai di ruang keluarga sambil nonton tv.

65. Zahra bantu potong kuku Ali.

66. Ali mendapatkan sms dari Dylan di kontak pesan Hp bahwa ia dan Zahra dia ajak nonton di bioskop.
67. Ayana terharu setelah menonton filem yang dipilihnya dengan Zahra, Ali, dan Dylan.

68. Zahra dan Ali bertemu Andra di depan bioskop.

69. Zahra dan Ali sampai di rumah.

70. Ali dan Zara ke Bandara Soekarno Hatta untuk pergi ke Lombok.

71. Ali dan Zahra jalan-jalan di Gili Trawangan.

72. Zahra dan Ali ke acara khitanan Adnan putra kedua Citra dan Danang.

73. Zahra sedih karena belum memiliki keturunan.

74. Zahra telah selesaikan S1 nya dan mendapatkan tempat magang di rumah sakit tempat Ali bekerja.

75. Penantian Ali dan Zahra telah terkabulkan, mereka akan menjadi orang tua karena Zahra positif hamil.

76. Dokter mengatakan proses persalinan Zahra akan berlangsung pada bulan januari minggu depan.

77. Setelah berjuang selama 8 jam, akhirnya sang buah hati lahir dengan selmat.

78. Ali, Zahra dan keluarga bahagia atas kehadiran bayi laki-lakinya bernama Shaka Pradipta Wiratama.

Berdasarkan hasil paparan dari sekuen-sekuen dalam novel Cinta Dalam Diam karya Shineeminka ini, dapat ditentukan tahapan-tahapan yang akan diuraikan dan diidentifikasikan mulai tahap pengenalan hingga penyelesaian seperti berikut.

Tahap perkenalan/penyituasian dalam novel ini berupa pengenalan tokoh-tokoh seperti Zahra, Ibu Zahra, Ali dan Ibu Ali. Pada awal cerita juga penulis memperkenalkan kebiasaan, sikap, serta hobi Zahra. Menceritakan bahwa Zahra adalah anak yang baik, penurut, dan juga sabar. seperti yang terlihat pada sekuen 1-3 yaitu ketika Ibu Zahra Mengajak Zahra ke rumah sahabatnya, yakni Tante Anisa. Zahra menggunakan pakaian Syar'i. Di sana ia diperkenalkan dengan anaknya Tante Anisa yang bernama Ali. Pada tahap ini pula menampilkan hal yang cukup 
penting terhadap perkembangan keseluruhan penceritaan dengan memberkan gambaran awal terhadap siapa dan bagaiamana tokoh. Selain itu, ia dapat pula menjelaskan bagaiamana suatu kondisi tertentu dapat mempengaruhi keberadaan tokoh-tokoh yang berperan di dalamnya.

Tahap pemunculan konflik. Terdapat pada sekuen 4-17. Seperti diketahui bahwa tahap ini merupakan tahap awal munculnya konflik dan konflik itu sendiri akan berkembang atau dikemabngkan menjadi konflik-konflik pada tahap berikutnya. Tahap ini memberikan pengenalan terhadap konsep mengenai sebuah konflik yang akan terjadi dan dialami oleh tokoh-tokoh dalam cerita. Tahapan ini konflik batin yang dimaksud bermula dari konflik yang ketika Zahra berkenalan dengan Ali, anaknya Tante Anisa yang sikapnya kurang baik sehingga membuat Zahra merasa kesal dengan sikap Ali. Ketika mereka sudah saling kenal, diam-diam kedua orang tua mereka telah menjodohkannya. Zahra yang merasa semuanya terlalu cepat, kaget dengan hal tersebut. Ali yang baru saja ia kenal ternyata ia akan menjadi calon pendamping hidupnya. Zahra yang menerima perjodohan itu walaupun dengan keterpaksaan. Zahra sangat menyayangi kedua orang tuanya dan ia tidak mau mengecewakan mereka.

Tahap peningkatan konflik. Terdapat pada sekuen 18-32. Pada tahap ini, konflik yang telah dimunculkan pada tahap sebelumnya semakin berkembang dan dikembangkan kadar intensitasnya. Tahap peningkatan konflik dalam novel ini ialah ketika Zahra mengetahu bahwa dirinya dijodohkan sama orang yang baru saja ia kenal dan ternyata anak dari sahabat mamanya. Mereka tidak saling kenal dan menikah atas dasar ingin meraih ridho Allah. Setelah menikah barulah Ali sadar bahwa wanita yang dia cintai bukan Zahra, saat dia melihat Ayanan di hari pernikahanya, dia baru sadar bahwa zahra hanya mirip dengan Ayana, yang rupanya adalah Bibi dari instrinya yang sekarang. Ali memiliki kisah cinta yang belum terselesaikan pada masa lalunya. Setelah menikah dengan Zahra, kisah cinta itu muncul kembali. Ali memiliki kisah cinta dengan tante Zahra sendiri. Perjalanan cinta Ali menjadi ujian perjalanan hijrahnya Zahra.

Tahap klimaks (konflik mencapi puncak) terdapat pada sekuen 37-55. Sebagai bentuk atau pertentanganpertentangan yang terjadi, yang diakui dan atau ditimpakan kepada para tokoh cerita mencapai titik intensitas puncak. Saat semuanya terungkap bahwa sebebnarnya Ali sangat mencintai Ayana bukan Zahra. Zahra mengalami keguguran akibat sikap suaminya. Zahra dan Ali tidak mengetahui bahwa istrinya tengah mengandung anaknya. Ali, Andara serta Danang mendengar perkaataan dokter bahwa Zahra mengalami keguguran yang baru saja memeriksa Zahra. Ali sangat menyesal karena ternyata istrinya sedang hamil. Danang dan Andara sontak marasa marah da kesal kepada Ali karena dia tidak menjaga Zahra dengan baik pada akhrinya Zahra kekeguran. Semua kelurga Zahra sangat menyesal kepada Ali karena telah menyakiti Zahra sehingga ia mengalami kekeguran. Dan pada akhirnya semunya tahu bahwa Ali sebenarnya masih mencintai Ayana. Setelah Zahra mulai sadar akhirnya Ia dan mamanya memutuskan akan pergi ke malang untuk menenangkan akanya peristiwa yang membuat hati anaknya sangat drop. Ali pergi ke malang untuk menyuusu sang istri. Di Malang Ali mengalami sakit disebabkan karena demam berdarah dan akhirnya dilarikan ka rumah sakit. Di tengah-tengah keluarga lagi berkumpul Ayana dan Danang datang menjenguk Ali dengan keadaan hamil. Danang mengatakannya kepada Ali bahwa Ayana hamil dan ayahnya adalah kamu, Ali.

Tahapan antiklimaks (konflik muli meredah) pada sekuen 54-60 saat Dylan yang secara diam-diam mengekuti Ayana ke Rumah sakit menjenguk Ali dan ia 
mengatakan bahwa anak yang dikandung Ayana adalah anaknya. Setelah semua telah terungkap Ayana mengakui kesalahanya bahwa sesungguhnya anak yang ia kandung bukanlah anak dari Ali akan tetapi dengan Dylan yaitu sahabtnya sendiri yang kini dia telah mengakui kesalahnya karena telah menyakiti Ayana. Ia juga meminta maaf kepada kelurga Zahra karena telah menyakiti perasaan mereka dengan sifat Ayana yang tidak terima dengan perlakuan kelurga Zahra yang selau meregut kebahagiannya. Kelurga Zahra dan Ali telah memaafkan Ayana yang sudah berperilaku jahat kepada mereka.

Tahapan penyelesaian terdapat pada sekuen 61-78 saat Ali meminta maaf atas semua kesalahan yang selama ini menyakiti Zahra. Mereka kembali menjalani hari-harinya dengan kebahagiaan karena semua keadaan telah membaik dan tidak ada lagi yang merusak rumah tangganya begitupun pula dengan Ayana, Dylan, Citra, dan Danang hidup bahagia dengan anak-anaknya. Ali dan Zahra memiliki kesempatan oleh Allah dengan menitipkan bayi yang kini tunmbuh di dalam perut Zahra padahal ia sempat di fonis oleh dokter kandungan bahwa kemungkinan besar ia hamil hanya $30 \%$ saja, sebab dia mengalami ganguan di rahim. Akhirnya tiba masa-masa meraka resmi menjadi ayah dan ibu ketika Sahka Pradipta Wiratama anak mereka lahir dengans selamat dan sehat. hari demi hari mereka hidup dengan kebahagiaan yang tak pernah mereka rasa sebelumnya. Ayana dan Dylan hidup bahagia dengan mengkaruniai sosok bayi laki-laki tampan. Danang sahabat Ali juga hidup dengan bahagia dengan mengkaruniai dua anak yang tampan.

Teknik pengaluran pun dalam novel ini tergolong alur campuran (majumundur), dikatakan demikian karena urutan peristiwa menceritakan secara berurutan kemudian di suatu titik cerita penulis membawa ke masa lalu tokoh, kemudian penulis membawa kembali pada masa sekarang toko. Untuk alur maju karena di awali saat Fatimah diminta menggunakan gamis, dan kerudung syar'i oleh ibunya saat mendatangi pengajian yang diadakan oleh sahabat ibunya. Di rumah tersebutlah Fatimah bertemu dengan Ali, yaitu pertemuan yang direncanakan oleh kedua orangtua mereka, yang berniat menjodohkannya. Hingga akhirnya mereka menikah, dan datanglah Ayana yang ternyata cinta pertama Ali, dan berkelanjutan hingga akhirnya Ali sadar bahwa dia ternyata yang dia lakukan selama ini salah. Alur ini juga mundur saat Ali yang mengingat pertemuannya dengan Ayana di Turki.

Konflik internal yang dialami tokoh utama Zahra adalah pertentangan antara menerima dan menolak perkataan Ibunya. Pada dasarnya tokoh Zahra memiliki karakter penurut, sabar dan berbakti kepada kedua orang tua. Peristiwa ini terjadi pada awal cerita sekaligus menjadi awal pengenalan tokoh dalam cerita. Berikut kutipannya:

"Aneh! Itulah pendaptku saat mengamati penampilanku di depan cermin. Bayangkan! Aku yang biasanya hanya mengenakan jins dan kameja lengan panjang saat menemani Mama bepergian, hari ini tak tahu kenapa malah disuruh Mama untuk memakai gamis!". "Iih...! Aneh bangat, Mah! Ganti ya? Zahra kelihatan kayak emak-emak kalau pake baju kayak ginian," rengekku. Enggak..., hari ini kamu harus pake baju itu!" perintah Mama tegas. "Please, Ma! Zahra nggak percaya diri kalau harus pake baju kayak gini," mohonku kembali. Semoga saja Mama mengizinkanku untuk mengganti baju gombrang ini dengan baju yang sudah biasa kupakai". "Masih sulit dipercayaa. Mana mungkin sih aku terlihat cantik pakai baju begini? Badan mungilku yang tingginya cuman seratus lima puluh senti lebih sedikit jadi kelihatan tambah kecil. Kalau Mbak Nisya sih memang terlihat cantik pakai baju macam ini. Mungkin karena ia memiliki perawakan 
seperti gadi-gadi Arab". (Shineeminka, 2018: 1).

Kutipan di atas menunjukkan bahwa terjadi konflik batin dalam diri Zahra. Pertama, Zahra adalah perempuan yang berparas cantik yang berpenampilan sesuka hatinnya. Kesehariannya sering mengenakan celana jins dan baju kameja panjang. Kedua, Zahra memiliki sifat yang manja kepada ibunya. Ketika Zahra diajak oleh ibunya ke rumah Tante Anisa untuk pengajian Zahra merasa aneh karena disuruh berpakaian seperti ibu-ibu. Zahra yang tidak terbiasa dengan pakaian yang begitu besar (gamis). Sedangkan keinginan Ibunya harus berpakaian muslimah sehingga dengan perbedaan ini akan munculnya konflik di dalam diri Zahra untuk mempertahankan keinginannya atau harus mengikuti keinginan ibunya dan pada akhirnya mengikuti perkataan ibunya.

Konflik batin berikutnya yaitu ia merasa bersalah kepada ibunya yang dari tadi nyariin di pengajian akan tetapi ia malah tidak ikut gabung. Berikut kutipannya:

"Kapan kamu mencontoh perilaku Fatimah az-Zahra?" Pertanyaan mama berhasil membuat diriku terpaku, mama membelai pipiku dengan lembut. "Mama menemanimu Zahra bukan tanpa alasan. Mama menemanimu seperti itu karena Mama berharap kamu akan menjadi perempuan sehebat Fatimah az-Zahra". Tak tahu kenapa, seketika aku ingin mengis mendengar ucapan Mama. "Maafin Zahra, Mah". Kupeluk erat tubuh Mama, tangis tak sanggup lagi kutahan.

"Ya Allah, betapa banyak kesalahan yang telah kulakukan selama ini. Betapa banyak rasa kecewa yang telah kutorehkan pada sosok wanita yang kini berada dalam pelukanku". (Shineeminka, 2018: 13).

Dari kutipan di atas, terjadi konflik dalam diri Zahra sebab kebiasaan yang selama ini dilakukannya ternyata tidak disukai oleh ibunya. Zahra sangat menyesal atas perbuatanya yang selalu tidak mengikuti perkataan Ibunya yang ketika di pengajian ia tidak ikut malah pergi ke belakang rumah Tante Anisa dan membaca buku, padahal ibunya berharap anak semata wayangnya itu bisa menjadi perempuan hebat seperti Fatimah az-Zahra seperti buku bacaannya yang sekarang ia pegang.

Konflik tokoh yang dialami oleh Ali, dalam cerita Ali adalah salah satu tokoh dalam cerita yang juga mengalami konflik bati, Ali adalah pemuda yang tampan, pekerja keras, karena diusia mudahnya dia sudah menjadi dokter, dan juga agamanya tinggi karena dia sama sekali tidak meladeni wanita-wanita yang tergila-gila padanya tapi tetap istiqomah di jalan yang diridai Allah.

Konflik batin yang dialami Ali yaitu ia menyesal karena sudah menjadi suami dari Zahra. Berikut kutipannya:

"Aku tak bisa, Nang... Aku telah mencarinya lebih dari lima tahun, pencarianku sia-sia selama lima tahun. Tapi kenapa ketika aku telah mengucap janji dengan Zahra, ia malah muncul tepat di hadapanku. Aku mencintainya, Nang... hingga detik ini cinta itu masih ada untuknya". (Shineeminka, 2018: 44).

Dari kutipan di atas menggambarkan bahwa Ali yang mencarinya selama lima tahun, tiba-tiba saja ia muncul di hari pernikahannya bersama Zahra yang kini sudah menjadi sepasangan suami istri yang sah, Ali yang sekarang tidak memikirkan wanita yang diimpikannya dulu, tiba-tiba saja wanita tersebut muncul dihadapannya. Ali sangat menyesal karena sampai sekarang ia masih mencintai wanita yang bernama Ayana yang bukan lain adalah Tantenya Zahra sendiri yang baru saja ia menjadi salah satu bagian dari kehidupannya.

Konflik batin Ali selanjutnya yaitu ketika Ali berdoa memohon kepada Allah atas sikapnya karena telah membuat Istrinya sakit hati. Berikut kutipannya:

"Ya Allah..., maafkan hamba yang telah menyakitinya," ucap Ali lirih. "Dia yang seharusnya kini kujaga... kuberi kasih sayang dan kebahagiaan... malah aku sakiti”. Berulang kali Ali mengucapkan 
istigfar, memohon ampun pada Allah karena telah menyakiti Zahra. Selama ini, Ali merasa ilmu agama yang telah ia pelajari mampu membentangi dirinya dari sesuatu yang dilarang oleh Allah. Namun, cinta pada pandangan pertama tak dapat ia tampik keberadaannya tepat lima tahun lalu. Saat itu, ia menjadi salah satu mahasiswa yang terpilih untuk menimba ilmu selama satu tahun di Turki. Ia bertemu dengan seorang gadis berwajah cantik. Bukan hanya kecantikannya, melainkan juga kecintaan gadis itu terhadap Alquran membuat Ali menaruh hati kepadanya. (Shineeminka, 2018: 47).

Dari kutipan di atas menggambarkan bahwa ketika Ali berdoa kepada Allah karena perbuatannya kepada Zahra yang seharusnya ia menjaga dan memberikan kebahagiaan justru ia sakiti dengan sikapnya karena seorang wanita yang masih sekarang ia suka karena sikapnya selalu membuat Ali menaruh hati padanya sehingga menyebabkan konflik di dalam diri Ali dimana ia mencintai Zahra sebagai istrinya akan tetapi di sisi lain ia juga masih sayang pada Ayana cinta pada pendangan pertamanya sewaktu kuliah di kairo.

Konflik tokoh yang dialami oleh Ayana, dalam cerita Ayana adalah salah satu tokoh dalam cerita yang juga mengalami konflik batin, Ayana adalah wanita yang jahat dan tamak, dia telah tahu bahwa lelaki yang dia cintai telah beristri, dan lelaki itu juga suami dari keponakannya sendiri, tapi dia tetap saja ingin merebutnya. Konflik batin Ayana yaitu ketika ia tidak bisa melupakan Ali cinta pertamanya yang kini sudah menjadi suami Zahra walapun sudah berusaha melupakannya. Berikut kutipannya:

Di atas sajadah, Ayana tersimpuh memohon kepada Allah, "maafkan aku, ya Allah..., Kau Maha Tahu apa yang tersimpan di dalam hatiku. Hanya namanya... hanya namanyalah yang selama ini tersimpan di dalam hatiku... aku sudah berusaha untuk membuang perasaan ini, namun ternyata aku tidak bisa melakukannya... aku mencintainya.. sangat mencintainya. Aku telah membalas surat cintanya”. (Shineeminka, 2018: 118).

Dari kutipan di atas menggambarkan bahwa Ayana meminta maaf atas apa yang dia perbuat. Ia tahu bahwa Allah tidak menyukai akan hal seperti itu, tapi karena ia tidak bisa melupakannya walaupun ia sudah berkeluarga, namun Ayana masih mencintainya. Dan ia pun membalas surat cintanya yang sempat kandas karena ketidak tahuan akan keberadaannya.

Selain konflik batin di atas, Ayana juga mengalami konflik batin karena kehilangan Ayah yang begitu di cintainya. Tepat seminggu setelah kematian sang ayah, ibunya ditemukan telah meninggal gantung diri. Berikut kutipannya:

"Ia kira... inilah penderitaan yang paling menyakitkan yang ia harus terima. Kehilangan ayah yang paling ia cintai dengan cara mengenaskan. Namun, ini bukan akhir dari penderitaannya... Ibu, satu-satunya orang yang ia jadikan tempat bersandar dan berlindung harus ikut pergi meninggalkannya. Tepat seminggu setelah kematian sang ayah, ibunya ditemukan telah meninggal gantung diri”. (Shineeminka, 2018: 172).

Dari kutipan di atas, tergambar dengan jelas bahwa Ayana benar-benar menderita atas kepergian kedua orang tuanya. Kehilanagan ayah yang begitu di cintainya dengan cara mengenaskan karena kecelakaan. Setelah kepergian ayah, tepat seminggu setelah kematian ayah, ibunya ditemukan meningal gantung diri. Kepergian Ibu untuk selamanya yang tak sempat ia saksikan saat menghembuskan nafas terahirnya membuat ia semakin menyesal dengan perbuatan ibu yang melakukan perbuatan bunuh diri dengan cara gantung diri sebab haram surga untukmu yang mnegakhiri hidupnya dengan secara sengaja. Belum kering air mata untuk kematian ayah, kini matanya kembali basah menangisi kepergian ibu yang sangat dicintainya.

Konflik tokoh yang dialami oleh Mama Zahra, dalam cerita Mama Zahra 
adalah salah satu tokoh dalam cerita yang juga mengalami konflik bati, Mama Zahra adalah salah satu tokoh dalam novel yang memiliki sikap yang tegas dan juga baik, dia mengajarkan anaknya dengan ajaranajaran yang sesuai syariat islam, walau agak memaksa, tapi semua itu karena dia tidak ingin anaknya terjerumus ke jalan yang sesat, dan tidak di ridhoi Allah SWT.

Konflik batin Mama Zahra yaitu ketika Anaknya mengalami keguguran dan menyesal menjodohkannya dengan Ali. Berikut kutipannya:

"Sang mama menatap Zahra dengan sedih. "Maafkan Mama... Andai saja dulu Mama dan Papa tidak megambil keputusan terlalu cepat, mungkin kau tidak akan mengalami hal semenyakitkan ini". (Shineeminka, 2018: 166).

Dari kutipan di atas menggambarkan bahwa Mama Zahra sangat kecewa atas perbuatan Ali yang sangat kejam kepada anaknya, Zahra yang mengalami keguguran. Ali yang selalu dipuji-puji akan sifat baik dan ilmu agamanya tinggi sehingga ia dipercayai untuk menjadi suami untuk anaknya, tapi semuanya telah berubah seketika anaknya mengalami keguguran.

Konflik sosial terjadi antara Mama Ayana dan Keluarga Zahra saat di rumah Ayana. Mama Ayana tidak menerima permintaan maaf atas kecelakaan yang menyebabkan suaminya meninggal karena keluarga Zahra. Berikut kutipannya:

"Ayah, bangun dong! Aya mau pergi ngaji bentar lagi". Teriakan ibunya membuat Ayana terdiam terpaku. "Kalian telah membunuh suamiku! Pergi kalian!. Aku tidak sudi melihat wajah kalian!". "Maaf... ini semua murni kecelakaan"."Maaf kalian tidak akan mengembalikan suamiku. Kalian pembunuh!”. Ayana memperhatikan semuanya dalam diam. Kemari siang sang ayah menjemputnya dari Madrasah dengan menggunakan sepeda. Ayana dibonceng di belakang, namun tiba-tiba ada sebuah mobil mewah yang menabrak mereka. Ayana terempas ke pinggir jalan yang dipenuhi rerumputan, namun ayahnya malah terlempar ke tengah jalan. Ada sebuah truk besar yang menggilas tubuhnya". (Shineeminka, 2018: 174).

Berdasarkan kutipan di atas menunjukkan bahwa Mama Ayana tidak menerima permintaan maaf dari keluarga Zahra sebab permintaan maaf kalian tidak akan mengembalikan suaminya. Mama Zahra mengusir keluraga Zahra yang telah membuat suaminya meninggal dunia karena ditabrak sehingga membuatnya marah sambil mengatai si pembunuh karena orang yang dicintainya telah tiada. Konflik sosial yang dialami Danang dan Ali berlanjut, kali ini Danang mengatakan bahwa Dokter Ali sangat bodoh. Dia seorang dokter tidak tahu kalau istrinya hamil dan sekarang ia mengalami keguguran. Berikut kutipannya:

Ali jatuh terduduk. Semua persendian tubuhnya mati rasa. "kau benar-benar bodoh, Al! Apa sih yang sebenarnya kaupikirkan?! Kau dokter... masa kau tidak tahu kalau istrimu sedang hamil dan sekarang ia keguguran...?! kau dengar, Al! Istrimu keguguran!". Kata-kata Danang benar-benar telah meremas hatiku. Ia benar-benar bodoh. Mungkin kata bodoh tidak cukup menggambarkan bagaimana dirinya sekarang". (Shineeminka, 2018: 155).

Berdasarkan kutipan di atas, dapat terlihat bahwa Danang sangat kecewa terhadap sahabatnya, Ali. Ali yang seketika jatuh duduk dan ia merasa tubuhnya mati rasa karena istrinya mengalami keguguran dan ia tidak tahu. Danang yang tidak percaya akan hal itu langsung mengatakan bahwa kau seorang dokter masa kau tidak tahu kalau istrimu hamil sehingga ia mengalami keguguran. Danang sangt marah kepada sahabatnya, Ali. Kau sangat bodoh Ali. Kata-kata Danang benar-benar meresahkan hati Ali. Mungkin kata bodoh tidak cukup menggambarkan bagaiamana dirinya sekarang yang tega memperlakukan Zahra tidak baik sehingga ia merasakan 
kehilangan atas bayi yang dikandung istrinya.

Konflik elemental adalah konflik yang disebabkan perbenturan tokoh dengan lingkungan sekitar dan alam. Konflik alam dialami Zahra saat berjalan kaki ke rumah Tante Anisa tiba-tiba saja ia kesandung di batu. Berikut kutipannya:

"Aww!" pekikku saat kakiku tersandung batu tanpa sengaja. Gila! Sakit bangat nih kaki! "Dasar, batu nyebelin1" dengan kesal, kutendang batu yang sudah membuat kakiku sangat sakit". (Shineeminka, 2018: 11).

Berdasarkan kutipan di atas, Zahra mengalami konflik elemental dengan alam. Konflik terjadi saat bunyi telepon dari Ibunya yang seketika itu dia masih di taman. Tanpa melihat siapa yang menelpon, Zahra sudah tahu kalau ini telepon dari Ibunya. Dengan langakahlangkah lebar, Zahra segera kembali ke kediaman Tante Anisa. Seketika kaki Zahra kesandung di batu tanpa sengaja. Dengan kesal, Zahra menendang batu yang sudah membuat kakinya sakit. Zahra yang tidak sadar kalau dia menendang batu yang malah membuat kakainya semakin sakit.

Konflik fisik diartikan adanya ketegangan antara tokoh-tokoh cerita yang berkaitan dengan perseteruan yang melibatkan anggota tubuh mnausia, seperti: meninju, menendang, demonstrasi, peperangan, baku hantam berkelahi, dan sebagainya.

Konflik fisik terjadi antara Ali dan Andra. Ketika mereka berada di rumah sakit. Ali tiba-tiba meniju Andra karena ia ternyata diam-diam mencintai istrinya. Berikut kutipannya:

Andra menjongkok tepat di depan Ali. "Andai Anda belum meminangnya. Sayalah yang akan meminangnya. Saya mencintainya".

"Ingatkah Anda dengan saya? Kecelakaan satu tahun yang lalu menimpa Anda. Saat itu, dia yang membawa Anda ke rumah sakit dengan mobilnya. Di saat itulah saya mencintainya".
Danang memegang bahu Ali saat tiba-tiba Ali meninju rahang Andra hingga membuat Andra terjerembab.

"Berani sekali kau mencintai istriku!" desis Ali marah. Ia sudah hendak kembali meninju Andra, namun ditahan oleh Danang. Andra beranjak bangun. "Andai malam ini saya tidak melihatnya menangis karena Anda, sungguh sampai kapan pun saya tidak akan mengatakan hal ini pada Anda. Saya akan mencintainya dalam diam", ucap Andra sebelumpergi meninggalkan Ali yang terlihat begitu emosi. (Shineeminka, 2018: 158).

Kutipan di atas menunjukkan pertarungan antara tokoh Ali dan Andra. Saat itu Ali dan Andra menunggu k ondisi Zahra yang sedang di periksa oleh dokter kandungan. Hasil dari pemeriksaan dokter bahwa Zahra mengalami keguguran. Ali yang menyesal saat ia mengetahui hal itu begitupun pula dengan Andra yang ternyata diam-diam telah mencintai istri Ali. Andra yang seketika itu berkata bahwa ia kecewa terhadap Ali yang telah tega berbuat jahat kepada Zahra. Andra seketika mengatakanya ke Ali bahwa ia sebenarnya mencintai Zahra. Sontak Ali marah dan emosi mendengar hal itu dan ia langsung meninju rahang Andra.

\section{SIMPULAN}

Berdasarkan hasil analisis data dalam novel Cinta Dalam Diam karya Shineeminka dengan menggunakan pendekatan objektif diperoleh kesimpulan sebagai berikut:

Bahwa konflik yang terdapat dalam novel Cinta Dalam Diam karya Shineeminka terdiri atas dua jenis yaitu, konflik internal dan konflik eksternal. Konflik internal terdiri atas konflik batin yang dialami oleh para tokoh dalam novel Cinta Dalam Diam karya Shineeminka, sedangkan konflik eksternal terbagi menjadi konflik sosial/antartokoh, konflik fisik dan konflik elemental yang di alami para tokoh dalam novel Cinta Dalam Diam karya Shineeminka. Konflik batin merupakan konflik yang terjadi pada diri 
tokoh dalam novel Cinta Dalam Diam karya Shineeminka meliputi tokoh utama Zahra, tokoh Ali, Ayana, dan Ibu Zahra. Konflik sosial/antartokoh merupakan pertentangan antara dua tokoh atau lebih dalam novel Cinta Dalam Diam karya Shineeminka meliputi, konflik Mama Ayana dan Keluarga Zahra, konflik sosial Ali dan Danang. Konflik elemental adalah konflik yang terjadi karena disebabkan adanya perbenturan dengan Alam atau lingkungan sekitar dalam novel Cinta Dalam Diam karya Shineeminka meliputi konflik fisik/alam yang dialami tokoh utama Zahra. Selanjutnya konflik fisik diartikan adanya ketegangan antara tokohtokoh cerita yang berkaitan dengan perseteruan yang melibatkan anggota tubuh mnausia, seperti: meninju, menendang, demonstrasi, peperangan, baku hantam berkelahi, dan sebagainya dalam novel Cinta Dalam Diam karya Shineeminka yang dialami tokoh Ali dan Andra.

Berdasarkan hasil dari penelitian tentag konflik dalam novel Cinta Dalam Diam karya Shineeminka ini, maka dikemukakan beberapa saran:

1. Hendaknya penelitian ini dijadikan sebagai tambahan referensi dalam menganalisis penelitian yang sejenis, khususnya konflik dalam novel.

2. Novel ini masih memiliki banyak hal menarik untuk di kaji, seperti karakter tokoh utama, pesan moral dan lain sebagainya, maka diharapkan agar diadakan penelitian selanjutnya tentang novel ini.

3. Novel ini sangat banyak berisi pelajaran bagi para remaja dalam pergaulan, maka para remaja sangat dianjurkan untuk membaca novel ini.

\section{REFERENSI}

Aminuddin. 2015. Pengantar Apresiasi Karya Sastra. Bandung: Sinar Baru Algensindo.

Faruk. 2017. Metode Penelitian Sastra. Yogyakarta: Pustaka Pelajar.
Hendy, Zaidan. 1991. Pelajaran Sastra I. Jakarta: PT Gramedia Widiasarana.

Jabrohim. 2017. Teori Penelitian Sastra. Yogyakarta: Pustaka Pelajar.

Lisnawati, Iis. 2019. Drama "Lelakon Raden Bei Surio" Karya F. Wiggers dalam Perspektif Pendekatan Struktural dan pendekatan Sosiologi. Jurnal Metabasa Volume 1, Nomor 1, Juni 2019. jurnal.unsil.ac.id.

Marsanti, Ena Putri. 2012. Aspek Kejiwaan Tokoh dalam Novel Sebelas Patriot Karya Andrea Hirata. BASASTRA Jurnal Penelitian bahasa, Sastra Indonesia dan Pengajarannya Volume 1, Nomor 1, Desember 2012 (ISSN 12302-6405). jurnal.fkip.uns.ac.id.

Nurgiyantoro, Burhan. 2013. Teori Pengkajian Fiksi. Yogyakarta: Gadjah Mada University Press..

Ratna, Nyoman Kuta. 2008. Teori, Metode, dan Teknik Penelitian Sastra. Yogyakarta: Pustaka Pelajar.

Redaksi PM. 2012. Sastra Indonesia Paling Lengkap. Jawa Barat: Pustaka Makmur.

Sakinah, R Myrna Nur. 2016. Konflik Antar Tokoh dan Agama dalam Novel Keluarga Purnama Karya Ramadhan K.H. Jurnal al-Tsaqafa Volume 13, Nomor 1, Januari 2016. https: //jurnal.uinsgd.ac.id.

Rasmandar, Ari. 2015. Analisis Konflik Tokoh Utama Dalam Novel Rembulan Tenggelam Di Wajahmu Karya Tere Liye. Jurnal Pendidikan dan Pembelajaran. V. 4, NO. 9. 2015.

Sayuti, Suminto A. 2017. Berkenalan dengan Prosa Fiksi. Yogyakarta: Cantrik Pustaka.

Sehandi, Yohanes. 2018. Mengenal 25 Teori Sastra. Yogyakarta: Penerbit Ombak.

Shineeminka. 2018. Cinta Dalam Diam. Depok: Bintang Media.

Siswanto, Wahyudi. 2013. Pengantar Teori Sastra. Yogyakarta: Aditya Media Publishing. 
Tarigan, Henry Guntur. 2015. PrinsipPrinsip Dasar Sastra. Bandung: CV Angkasa.

Teeuw, A. 2015. Sastra dan Ilmu Sastra. Bandung: PT. Dunia Pustaka Jaya.

Wicaksono, Andri. 2014. Pengkajian Prosa Fiksi. Bandung: Garudhawaca.

Wellek, Rene dan Austin Warren. 1995. Teori Kesusastraan. Jakarta: PT Gramedia Pustaka Utama. 